ISSN (print): 2644-0490, ISSN (online): 2644-0504

Volume 4 Issue 07 July 2021

Article DOI: 10.47191/jefms/v4-i7-23, Impact Factor: 6.228

Page No. 1092-1108

\title{
The RICO Law and The MAGNITSKY Law - the solution for fighting corruption and the mafia in European Commission and Bulgaria - on the example of the "real owner" of the state company BULGARIAN POSTS JSC and the theft and loss of an American company for $\$ 250$ billion
}

\author{
Lord Prof. PhD PhD Momtchil Dobrev-Halachev \\ Scientific Research Institute Dobrev \& Halachev.JSC., Sofia.Bulgaria
}

\begin{abstract}
Lord prof PhD PhD Momtchil Dobrev-Halachev and Prof. Mariola Garibova-DObreva developed 2006 "Theory of degree of democracy" and "Theory of degree of justice / injustice /" based on their practice in court, prosecutor's office, state. Prof. Momchil Dobrev has been creating Theory of Corruption, "Theory of the Mafia," Theory of Mafia "," Financial Banking Resource Technological Mafia Materialism "since 2003"
\end{abstract}

KEYWORDS: RICO Law, Magnitsky Law, mafia, corruption, theory, finance.

\section{INTRODUCTION}

Lord Prof. PhD PhD Momtchil Dobrev-Halachev and Prof. Mariola Garibova-DObreva developed 2006 "Theory of degree of democracy" and "Theory of degree of justice" based on their practice in court, prosecution, state and especially the practice of Prof. Mariola Garibova-Dobreva as a judge for decades of experience as such as a civil and criminal judge and Prof. Momchil Dobrev participated as an observer in various types of elections. Prof. Momchil Dobrev created 2001 Theory of Corruption and Theory of Mafia and Theory and Practice of Mafia, which contribute to clearing the Theory of the degree of democracy.

In the year 2001 Lord Prof. Momtchil DObrev developed the Theory of the mafia and Theory of corruption. All the both theories has been developed by analyzing the mafia and the corruption all over the wprld. In Bulgaria, germany, European Union, and other countires.

In the year 2010 Lord Prof. Momtchil Dobrev developed the 'Theory of Mafiotismus' as a new type of government oriented solely in the private interests of individuals and private institutions.

The fight against the mafia and corruption in Bulgaria and in the European Commission and the European Union does not yield results because the mafia is at the highest state and European level and does what it wants. This mafia holds courts, prosecutors and all kinds of state institutions and the latter carry out its orders.

Here we will consider a case in which losses of over 250 billion USD are caused to the real owner - an American company of the Bulgarian state company "Bulgarian Posts" by the mafia in Bulgaria and the European Commission.

\subsection{Introduce the Problem}

The problem with the mafia and corruption in Bulgaria and in the European Union and the European Commission is huge. We have repeatedly applied evidence of the scale of this mafia. The basis of this mafia and corruption in Bulgaria and the European Union and the European Commission, Lord Prof. Momchil Dobrev, established in 2001. Mafia Theory and Corruption Theory with all its manifestations. Based on these theories, Lord Prof. Momchil Dobrev also defines the formula of the mafia, the formula of corruption. Based on these processes, Lord Prof. Momchil Dobrev created the Theory and Practice of Mafism, defining a formula of mafia, how it works, how it is organized, in whose interests it works at its expense.

Corruption and the mafia in a country destroy democracy, freedoms, human rights, the rule of law. As a result lor. Prof. Momchil Dobrev and Lady Prof. Marioal Garibova-Dobreva also created "Theory of the Degree of Democracy" and "Theory of the Degree of Justice / Injustice" as well as "Theory of Socio-Humanism" - a society that excludes the shortcomings of 
The RICO Law and The MAGNITSKY Law - the solution for fighting corruption and the mafia in European Commission and Bulgaria - on the example of the "real owner" of the state company BULGARIAN POSTS JSC and the theft and loss of an American company for $\$ \mathbf{2 5 0}$ billion

neoliberalism, globalism, wild market economy, and creates the foundations of a NEW HUMAN SOCIETY based on completely different principles, as well as economic and social, managerial and others.

As a result of the struggle of Lord Prof. Momchil Dobrev against corruption and the mafia in Bulgaria and the European Union and the European Commission since 2011. Lord Prof. Momchil Dobrev experienced 9 / nine / attempted murders of him and his relatives.

As a result and the only solution for the fight against corruption, Lord Prof. Momchil Dobrev sees only the application of the MAGNETIC LAW and the RICO LAW in the fight against this corruption and mafia in Bulgaria and in the European Union and the European Commission.

\section{RESEARCH METHODS}

Research methods of analysis, verification, control of all factors in corruption and the mafia that affect a society for its viability, the degree of democracy in that society, laws, their implementation by judges, prosecutors, statesmen, ministers, minister Chairs, state and municipal officials and others.

- Analysis of the laws of a country and the European Commission

- Analysis of all authorities in a country - judicial, legislative, executive and the European Union and the European Commission

- Analysis of the implementation of the laws of a country and the European Commission

- Analysis of governance in a country and a society and the European Commission

- Analysis of public resource management in a country and the European Commission

- Analysis of the existence of corruption and mafia in the judiciary, in the state system and in the European Union.

- Analysis of the work of the prosecutor's office as a guarantor of the existence and development of mafia and the rule of law in a society.

- Analysis of the judiciary - laws, judges, selection of judges, development of judges, violations of judges, disciplinary and other liability of judges, prosecutors, investigators, guarantors of democratization in a society

3. The RICO Law and The Magnitsky Law - the solution and guarantee for the fight against corruption and the mafia at the state level in Bulgaria and the European Commission, Theory of the Mafia, The Theory of Corruption, Theory of Mafiotismus by Prof. Momchil Dobrev

The formulas of mafia, mafiotismus, corruption, degree of democracy, degree of justice

\subsection{The Rico Law And Magnistky Law}

The Racketeer Influenced and Corrupt Organizations (RICO) Act is a United States federal law that provides for extended criminal penalties and a civil cause of action for acts performed as part of an ongoing criminal organization.

The RICO Act focuses specifically on racketeering and allows the leaders of a syndicate to be tried for the crimes they ordered others to do or assisted them in doing, closing a perceived loophole.

For example, before RICO, a person who instructed someone else to murder could be exempt from prosecution because they did not personally commit the crime.

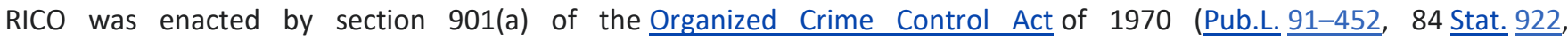

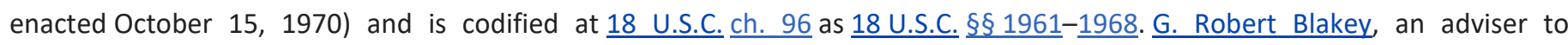
the United States Senate Government Operations Committee, drafted the law under the close supervision of the committee's chairman, Senator John Little McClellan. It was enacted as Title IX of the Organized Crime Control Act of 1970, and signed into law by US President Richard M. Nixon.

While its original use in the 1970s was to prosecute the Mafia as well as others who were actively engaged in organized crime, its later application has been more widespread.

Beginning in 1972, 33 states adopted state RICO laws to be able to prosecute similar conduct.

Under RICO, a person who has committed "at least two acts of racketeering activity" drawn from a list of 35 crimes27 federal crimes and 8 state crimes - within a 10-year period can be charged with racketeering if such acts are related in one of four specified ways to an "enterprise." Those found guilty of racketeering can be fined up to $\$ 25,000$ and sentenced to 20 years in prison per racketeering count.In addition, the racketeer must forfeit all ill-gotten gains and interest in any business gained through a pattern of "racketeering activity." 
The RICO Law and The MAGNITSKY Law - the solution for fighting corruption and the mafia in European Commission and Bulgaria - on the example of the "real owner" of the state company BULGARIAN POSTS JSC and the theft and loss of an American company for $\$ \mathbf{2 5 0}$ billion

When the U.S. Attorney decides to indict someone under RICO, they have the option of seeking a pre-trial restraining order or injunction to temporarily seize a defendant's assets and prevent the transfer of potentially forfeitable property, as well as require the defendant to put up a performance bond. This provision was placed in the law because the owners of Mafiarelated shell corporations often absconded with the assets. An injunction or performance bond ensures that there is something to seize in the event of a guilty verdict. In many cases, the threat of a RICO indictment can force defendants to plead guilty to lesser charges, in part because the seizure of assets would make it difficult to pay a defense attorney. Despite its harsh provisions, a RICO-related charge is considered easy to prove in court since it focuses on patterns of behavior as opposed to criminal acts.

RICO also permits a private individual "damaged in his business or property" by a "racketeer" to file a civil suit. The plaintiff must prove the existence of an "enterprise." The defendant(s) are not the enterprise; in other words, the defendant(s) and the enterprise are not one and the same. There must be one of four specified relationships between the defendant(s) and the enterprise: either the defendant(s) invested the proceeds of the pattern of racketeering activity into the enterprise (18 U.S.C. § 1962(a)); or the defendant(s) acquired or maintained an interest in, or control of, the enterprise through the pattern of racketeering activity (subsection (b)); or the defendant(s) conducted or participated in the affairs of the enterprise "through" the pattern of racketeering activity (subsection (c)); or the defendant(s) conspired to do one of the above (subsection (d)). In essence, the enterprise is either the 'prize,' 'instrument,' 'victim,' or 'perpetrator' of the racketeers. A civil RICO action can be filed in state or federal court.

Both the criminal and civil components allow the recovery of treble damages (damages in triple the amount of actual/compensatory damages)

\section{MAGNISTKY LAW}

The Magnitsky Act fights corruption on a global scale, in defense of human rights. The Magnitsky Act fights against every corruption and mafia in a country, against corrupt practices at every level in a country, against corrupt practices. The Magnitsky Act is an opportunity to fight the oligarchy in one country, to fight the mafia in one country, the mafia at any level in one country. The Magnitsky Act became law on December 14, 2012 during the presidency of President Barack Obama.

The scope of the Magnitsky Act allows the United States to impose sanctions on politicians, government officials, their assistants, and administrations that violate human rights and engage in widespread corruption. The consequences are sanctions, blocking of assets, bank accounts of the sanctioned persons and their relatives of assets around the world, freezing of assets, bank accounts, blocking of transactions, international transfers in dollars.

Magnitsky's application of the law by the United States occurs when the United States decides to intervene in corruption schemes in a country, its practices, schemes, restrictions on human rights, in order to restore the rule of law.

At the moment, the fight is between crime and the rule of law. When crime has reached its peak, corruption schemes, mafia practices rule in a society, and thus destroy democracy, justice, the rule of law.

3.2./. Mafia Formual, Corruption Formula , Mafiotismus Formula, DEMOCRACY FORMULA, JUSTICE / INJUSTICE DEGREE, Confidence Formula, Truth Formula.

CORRUPTION FORMULA / 2001 - Theory of Corruption - Prof. Momchil Dobrev

Corruption FORMULA -2001 = Monopoly rights / rights + laws / rules / practices / procedures + possibility to make an alternative decision - obligation - responsibility - morality / ethics.

MAFIA FORMULA - 2001 - Mafia Theory - Prof. Momchil Dobrev

MAFIA = Power + Influence + Relationships + Interests + ORDER / And + Mafia structure / internal or external structure / + Monopoly rights / rights + laws / rules / practices / procedures + possibility to make an alternative decision - obligation responsibility - morality / ethics .

FORMULA OF MAFIOTISM - 2001 - Theory of Mafiaism - Prof. Momchil Dobrev

MAFIOTISMUS = PERSONAL Power $/$ on the top of the state institutions / state and etc./ + Influence + Connections / to personal, private companies + Interests / personal, private, corporative / + ORDER / ORDERS + Personal Management of all state neveaus + Personal Control of all state niveausMafia structure / inside of or outside / + Monopolity Riegths + laws / 
The RICO Law and The MAGNITSKY Law - the solution for fighting corruption and the mafia in European Commission and Bulgaria - on the example of the "real owner" of the state company BULGARIAN POSTS JSC and the theft and loss of an American company for $\$ \mathbf{2 5 0}$ billion

rules / practices / procedures + possibility of taking an alternative decision - obligation - responsibilities - morality / ethics + Personal management and personal control of Distribution of public state monetary and another resource.

FORMULA of DEGREE OF DEMOCRACY / 2006 - Prof. M.Dobre and Prof. M.Garibova-Dobreva

DEMOCRACY = POWER - Influence - Relationships - Interests - ORDER / AND - Mafia / mafia structure / internal or external / - Monopoly rights + laws / rules / practices / procedures // freedoms // - possibility to make an alternative decision - Obligation - Responsibility - morality / ethics - observance / application / enforcement of the law by judges / prosecutors / statesmen - Control / Sanction - corruption / corrupt practices - information - manipulation - society structure - economy inequality + obligations - Justice / injustice - Trust / Degree of trust

FORMULA of Degree of Justice / Injustice - 2006 - Prof. Momchil Dobrev and Prof. Mariola Garibova-Dobreva /:

JUSTICE $/$ INJUSTICE $=$ POWER + Influence + Relationships + Interests + MONEY / And + Mafia structure $/$ internal or external / + Monopoly rights / rights + laws / rules / practices / procedures + possibility to make an alternative decision Obligation - Responsibility - morality ethics - observance / application / implementation of the law by judges / prosecutors / statesmen - Control / Sanctions - Corruption - Mafiaization - TRUST / DEGREE OF TRUST.

THE DEGREE of Justice / Injustice depends on the degree of MAFIOTISM in a society, the degree of corruption among law enforcement and law enforcement agencies, the degree of trust of civil society in all participants in government - court, state prosecutor's office, how and whether judges and prosecutors obey the law, enforce the law, enforce the law, fail to enforce, break the law prosecutor's office, state, municipalities., depends on the degree of truth.

The DEGREE OF DEMOCRACIZATION OF A SOCIETY depends on the respective DEGREE OF UNJUSTICE / JUSTICE.

3.3. THE MAFIA IN BULGARIA and the inaction and support of this mafia by the EUROPEAN COMMISSION and the EUROPEAN UNION

BULGARIA - THE MAFIA HAS A STATE

THE INACTION AND SUPPORT OF THIS MAFIA BY THE EUROPEAN COMMISSION AND THE EUROPEAN UNION.

We will not go into details and therefore we will pay attention to what is the reason for the current state of our country. In our homeland:

Corruption has become the norm. The mafia has become the norm.

That the Prime Minister has appointed the Chief Prosecutor has become NORM. It is clear why!

The fact that the prosecutor's office does not bring charges against ministers and prime ministers and statesmen has become NORM. It has become the norm for the prosecutor's office to raise fabricated accusations against dissidents and against fighters against the mafia and corruption.

Public procurement has become the norm of corruption and the mafia.

It is the norm that the price of $30 \%$ of the public procurements, at least for European projects and any other countries and others, should go for commissions, for the mafia.

It is even the norm that these percentages are negotiated and signed notarized by a notary close to the mafia.

It is the norm for prosecutors in the specialized prosecutor's office to cover up clearly proven crimes committed by judges, legalizing theft of property for hundreds of millions, legalizing theft of property, legalizing theft of equipment for tens of millions, legalizing theft of entire factories, and legalizing overtly proven crimes. judges, mayors of the capital and others?!?!?!

NORMA is for prosecutors to delay pre-trial proceedings for years against people supported by the mafia, with the ultimate goal of passing the statute of limitations.

NORMA is for prosecutors to violate the laws of our country with the ultimate goal of fulfilling the order - TIGHTENING ZADAR over a person close to the mafia, an official, a minister, a prime minister, and others.

NORMA is prosecutors to RAISE ACCUSATIONS against appointed people, critics of the mafia and people of the mafia, who are in violation of the law with the ultimate goal of racketeering, coercion, RUIN OF HUMAN LIVES, FATE, deterioration of health.

NORM is that prosecutors do not respect the laws when it comes to people close to the mafia,. 
The RICO Law and The MAGNITSKY Law - the solution for fighting corruption and the mafia in European Commission and Bulgaria - on the example of the "real owner" of the state company BULGARIAN POSTS JSC and the theft and loss of an American company for $\$ \mathbf{2 5 0}$ billion

It is the norm for prosecutors, in case of indisputable evidence, graphological expertise for fraud on a particularly large scale, to delay investigations in order to pass the statute of limitations against the perpetrators, who boast that they pay prosecutors not to charge them.

It is the norm for mafia judges to confirm these terminations by prosecutors despite indisputable evidence. / example M. Lalov/

It is the norm for judges to place orders for the mafia and to issue decisions that legalize the theft of private property in favor of the Sofia Municipality - the GERB representatives.

It is the norm for judges to place orders for the mafia and to legalize thefts of factories, equipment worth tens of millions of euros, theft of property for the benefit of third parties.

NORMA is for judges to terminate cases against banks, insurance companies, state institutions, ministries, the National Revenue Agency, the Ministry of Interior in execution of an order of the executive branch and of mafia companies.

NORM is to disappear lawsuits filed against Banks for stolen money - hundreds of thousands of levs, millions of levs, for damages - losses of billions.

NORM is to disappear lawsuits against state companies, state institutions for proven damages, losses, crimes.

THE NORM is for cases against the PEAs to disappear from the mafia.

THE NORM is to terminate cases for RESTORATION OF PROPERTIES STOLEN BY THE MAFIA AND THE CITY MUNICIPALITY.

THE NORM is to LEGALIZE CRIMINALS COMMITTED BY THE EXECUTIVE POWER WITH DECISIONS OF JUDGES.

It is the norm for judges to make absurd decisions by violating the laws, not recognizing the laws, with the ultimate goal of repressing the plaintiffs in order to lose money - tens - millions of levs, TO MAKE THE ORDER OF THE MAFIA.

It is the norm for prosecutors not to bring charges against judges who have violated the Penal Code and the laws, because these judges serve the mafia.

LEGALIZATION OF RACKETS IS THE NORM.

The norm is for a state project to be given to a company close to the Prime Minister and his entourage, which should be reported accordingly.

It is the norm for the prosecutors of Filchev, Assoc. Prof. Boris Velchev, Tsatsarov and Geshev not to file charges for the theft of property by the oligarchs Emil Kyulev, Donev - properties that belong to the heirs of insurance companies.

It is the norm for the prosecutors of TSATSAROV and GESHEV and for them personally not to bring charges for the theft of land over 2.9 million cubic meters of land from private land, with which the NORTH TANGENT of the city of Sofia was built, personally notified TSATSAROV and GESHEV.

NORM is from 2008. not to be ACCUSED against PEA Dichev, PEA Yakimov, PEA. Cholakov and dozens of other PEAs violated the law.

NORMA is the double standard in the prosecution.

THE NORM is to terminate cases for RESTORATION OF PROPERTIES STOLEN BY THE MAFIA AND THE CITY MUNICIPALITY.

THE NORM is to LEGALIZE CRIMINALS COMMITTED BY THE EXECUTIVE POWER WITH DECISIONS OF JUDGES.

It is the norm for judges to make absurd decisions by violating the laws, not recognizing the laws, with the ultimate goal of repressing the plaintiffs in order to lose money - tens - millions of levs, TO MAKE THE ORDER OF THE MAFIA.

It is the norm for prosecutors not to bring charges against judges who have violated the Penal Code and the laws, because these judges serve the mafia.

LEGALIZATION OF RACKETS IS THE NORM.

Racketeering and coercion by the NRA IS THE NORM - IN VIOLATION AND NON-ENFORCEMENT OF JUDGMENTS ENTERED INTO FORCE.

RACKET AND FORCE FROM THE PROSECUTOR'S OFFICE IS THE NORM.

RACKETS, FORCED BY STATE INSTITUTIONS, AGCC FOR THEFT OF PROPERTY, IS THE NORM. THE LEGALIZATION OF EXTORTION and coercion by prosecutors and judges is NORM. THE NAMING OF MAFIA PEOPLE IS THE NORM. Hiring people for money is NORM.

INJUSTICE is the NORM. THE LEGISLATION by judges and prosecutors is NORM.

IMPUNITY is the NORM. LAWLESSNESS IS THE NORM.

FAILURE TO COMPLY WITH THE LAW is a NORM. VIOLATION OF THE LAW is a NORM.

ABUSE AND THEFT OF PUBLIC RESOURCE IS THE NORM. Public procurement organized for a specific candidate is NORM.

The NORM is to ruin agriculture by ensuring that intermediaries earn hundreds of times more than the producers themselves. 
The RICO Law and The MAGNITSKY Law - the solution for fighting corruption and the mafia in European Commission and Bulgaria - on the example of the "real owner" of the state company BULGARIAN POSTS JSC and the theft and loss of an American company for $\$ \mathbf{2 5 0}$ billion

The NORM is to ruin businesses in Bulgaria to ensure that foreign companies enter the Bulgarian market and profit from it, at the expense of Bulgarian producers.

THE NORM is THE THEFT OF BUSINESS by people from the mafia.

THE STANDARD IS PROPERTY THEFT by people from the mafia.

THE NORM IS THAT THERE IS NO JUSTICE, THERE IS NO JUSTICE.

THE NORM IS THE INACTION OF THE EUROPEAN COMMISSION AND THE EUROPEAN PARLIAMENT despite the application of evidence of the mafia in a country, the mafia in court, the mafia in the prosecution, the mafia in the government of Bulgaria.

Bulgaria is used only for money laundering, $\mathbf{3 0}$ to $\mathbf{5 0}$ percent of all investments in equipment, machinery, investments are returned to the company of EUROPE and Western countries.

DEMOCRACY AND THE DEGREE OF DEMOCRACY DEPENDS ON THE FOLLOWING FACTORS AND THEIR DEGREES AS FOLLOWS / short description /:

GOVERNANCE - transparent governance in the state, governance in the state in favor of third parties, governance in the state in favor of the oligarchy, imposition of taxes in favor of the oligarchy, absorption of public resources for the benefit of third parties, utilization of public resources in public procurement in benefit of a specific third party, uncontrolled spending of public resources, lack of control over corrupt decisions

PARLIAMENT - dependence on the oligarchy, dependence on the mafia, disregard / non-application / non-fulfillment of laws, adoption of laws in violation of the public interest, adoption of laws in violation of the Constitution, adoption of laws in favor of the oligarchy, adoption of laws violating human rights, dependencies on different interests / lobbying

JUDICIARY - What determines injustice / SPRAVELIVOSTTA in the judicial system: legality - pass laws, law enforcement, Duality of law enforcement, confrontation and contradiction PPIETITE law with the Basic Law of control, JUDGMENTS, equality, implementation monitoring law by judges overseeing the implementation of the law by the prosecutor overseeing the implementation of laws by government, ministers „, CONTROL OF IMPLEMENTATION OF THE LAWS OF MUNICIPAL / LOCAL POWER, CONTROL OF IMPLEMENTATION OF THE LAWS OF mINISTERS AND BY THE PRIME MINISTER the prosecution DEPENDENCE OF pROSECUTION OF THE EXECUTIVE dependence prosecution by the mafia in its favor, DEPENDENCE OF jUDGES OF mAFIA, the violation of law by judges, impunity of judges, impunity prosecutors impunity for officials, CONTROL OF JUDGMENTS OF EVIDENCE, CONTROL OF JUDGMENTS - IMPACTED PRACTICE, FAILURE OF JUDGMENTS OF JUDGES, THE FAILURE OF THE DIRECTIVES REGULATIONS OF SADIIOT EVROPEYSKATATA COMMISSION AND THE EUROPEAN UNION, THE FAILURE OF JUDGMENTS H \EPRILAGANE of judgments BREACH OF JUDGMENTS FAILURE OF LAWS, DISAPPLICATION the law, breaking the law, MAFIOTIZATSIYA OF THE COURT, MAFIOTIZATION OF THE PROSECUTOR'S OFFICE, MAFIOTIZATION OF THE STATE APPARATUS, MAFIOTIZATION IN THE LOCAL MUNICIPAL APPARATUS, IMPLEMENTATION OF THE CONSTITUTION (

HUMAN RIGHTS AND FREEDOMS - perform basic civil rights, confrontation between different groups of people, confrontation on religious grounds confrontation cultural basis CONFRONTATION OF ACADEMIC LEVEL - background, confrontation OBSHTEISTVENO LEVEL confrontation CO / occasion LEVEL CONFRONTATION AT THE LEVEL OF BUSINESS - MONOPOLY, OLIGOPOL AND OTHERS

CORRUPTION - DEGREE OF CORRUPTION WITH JUDGES, CORRUPTION WITH PROSECUTORS, CORRUPTION WITH STATES / MUNICIPALITIES / MINISTERS / PRIME MINISTERS, MAFIA

HUMAN RIGHTS - RESPECT FOR HUMAN RIGHTS, APPLICATION OF HUMAN RIGHTS LAWS,

Inequality and ELECTIONS - RETURN OF THE POPULATION CITIZEN PARTICIPATION IN ELECTIONS / IN AGE / CITIZEN PARTICIPATION IN ELECTIONS / Earnings / PARTICIPATION GRAGZHDANTE in elections / FOR EDUCATION / enforcement of laws by government enforcement of laws by ministers, ENFORCEMENT OF LAWS BY THE PRIME MINISTER, VIOLATION OF THE LAWS BY MINISTERS, VIOLATION OF THE LAWS BY THE PRIME MINISTER

DEGREE OF VALUE SYSTEMS / MORALS

- Personal value system 
The RICO Law and The MAGNITSKY Law - the solution for fighting corruption and the mafia in European Commission and Bulgaria - on the example of the "real owner" of the state company BULGARIAN POSTS JSC and the theft and loss of an American company for $\$ \mathbf{2 5 0}$ billion

- Spiritual value system public values

- Career value system

- Family value system

- Cultural value system

- Social value system

\section{INEQUALITY IN SOCIETY}

SOCIAL INEQUALITY / depending on education /, SOCIAL INEQUALITY / depending on secondary education, SOCIAL INEQUALITY / depending on higher education /, SOCIAL INEQUALITY / depending on age / SOCIALLY / SOCIALLY / dependence on religion, SOCIAL INEQUALITY / depending on culture, SOCIAL INEQUALITY / depending on the minority /, SOCIAL INEQUALITY / depending on

\section{PRESENCE OF CORRUPTION AS A PROBLEM OF DEMOCRACY FIELDS OF CORRUPTION}

Corruption can be detected in all spheres of public life. It is determined by the available management practices, bureaucratic traditions, political and economic development, the specifics of a society, socio-cultural environment, laws, morals, rules, norms, morals and ethics of behavior of citizens.

\section{Areas of manifestation of corruption are:}

1 /. The sphere of state administration. This includes government, government departments, and institutions, local governments, and others.

2/. The sphere of politics-. This includes parliament, political parties, trade unions, movements, business and non-profit associations.

3 /. The sphere of the judicial system / judges /

4 /. The sphere of law enforcement institutions / prosecutor's office, investigation services, police /

5 /. The sphere of public services - healthcare, education, social assistance and others.

6/. The sphere of the private sector - business organizations, companies both local and international, global and transnational.

7 /. The field of media / radio, television, newspapers, magazines and other media /

8 / The sphere of the "civil sector

\section{Manifestations before judges of corruption / lawlessness / mafia:}

1. Degree of interest,

2. degree of incompetence,

3 degree of alleged incompetence,

4 degree of kinship,

5 degree of official bias,

6 degree of judicial solidarity,

7 degree of inaction,

8 degree of delayed action,

9 degree of regional bias - bias towards fellow citizens - the region, the city,

10 degree of bias towards related services and others,

11 degree of bribery,

12 degree of resolving a court case not according to the established member, but according to another or non-existent in the respective claim,

13 degree of "nagging" - finding any non-existent reasons to linger in the case or leave without movement,

14 Degree of interest of the judge in the relevant decision in a case

15. Degree of interest of a third party in the decision in a case

16. Degree of interest of a senior manager in the court of a specific decision

17. Degree of implementation of the law by a judge

18. Degree of proper application by a judge

19. Degree of correct interpretation of a law by a judge 
The RICO Law and The MAGNITSKY Law - the solution for fighting corruption and the mafia in European Commission and Bulgaria - on the example of the "real owner" of the state company BULGARIAN POSTS JSC and the theft and loss of an American company for $\$ \mathbf{2 5 0}$ billion

20. Degree of violation of the law by a judge

\section{Manifestations at the prosecutor's office:}

1 Degree of interest,

2 Degree of incompetence,

3 Degree of bias,

4 Degree of alleged incompetence,

5 Degree of kinship,

6 Degree of service bias,

7 Degree of prosecutorial solidarity,

8 Degree of bias towards the citizen,

9 Degree of bias towards related services and others,

10 Degree to bribe,

11 Degree of inaction,

12 others.

Manifestation with state / municipal / tax officials:

1 Degree of inaction,

2 Degree of alternative decision making,

3 Degree of delay in decision-making.

4 Degree to bribe,

5 Degree of issuance of inside information,

6 Degree of interest in tenders, privatization,

7 others.

\section{MAFIOTIZATION}

1 /. Degree of mafiaization in the field of state administration. This includes government, government departments, and institutions, local governments, and others,

2 /. Degree of mafiaization of the sphere of politics-. This includes parliament, political parties, trade unions, movements, business and non-profit associations,

3 /. Degree of mafiaization of the sphere of the judiciary / judges /, -

4 /. Degree of mafiaization in the field of law enforcement institutions / prosecutor's office, investigation services, police /, -

5 /. Degree of mafiaization in the field of public services - health care, education, social assistance, etc.

$6 /$. Degree of mafiaisation in the private sector, -

7 /. Degree of mafiaization in the field of media / radio, television, newspapers, magazines and other media /, -

8 / Degree of mafiaization in the sphere of the "civil sector" / civil associations, non-governmental organizations and others /

\section{DEGREE OF CORRUPTION}

1. Degree of corrupt action to ensure access to limited resources, benefits, rights or limited costs for obtaining them.

2. Degree of corrupt action for the performance of a lawful action and decision by the administrative service.

3. Degree of corrupt action to obtain benefits controlled by decision-makers on personal preference.

4. Degree of corrupt action to prevent the use of certain resources, benefits, rights by other stakeholders and individuals.

5. Degree of corrupt action for the provision of a service related to the use of inside information or to expedite a specific decision.

6. Degree of corrupt action - inaction for performing a lawful action or making a lawful decision.

The forms of corruption in the public administration are the following:

1. Degree of non-fulfillment of a legal request by a person entitled to do so by an employee of the respective administration. Manifested in open refusal, tacit refusal and others.

2. Degree of interest in favor of third parties when the government or the relevant administration, body, institution is a seller. 
The RICO Law and The MAGNITSKY Law - the solution for fighting corruption and the mafia in European Commission and Bulgaria - on the example of the "real owner" of the state company BULGARIAN POSTS JSC and the theft and loss of an American company for $\$ \mathbf{2 5 0}$ billion

3. Degree of interest in favor of third parties when the government or the relevant administration, body, institution is a buyer or user of certain services.

4. Degree of interest in favor of third parties when state and other institutions - municipal carry out right-wing transactions.

5. Degree of interest in favor of third parties when the executive power controls financial and credit institutions, companies with licenses, companies with concessions, permits and others.

6. Degree of interest in favor of third parties when the executive power distributes limited funds, subsidies, grants, investments, social payments and others.

7. Degree of interest in favor of third parties When there is a service for granting and authorizing specific activities, permits, licenses and other regimes for performing a specific activity.

8. Degree of interest in favor of third parties in the collection of taxes, fees, duties

9. Degree of interest in favor of third parties in collecting fines, sanctions

10. Degree of interest in favor of third parties when state and other types of employees are authorized and authorized to perform control functions and to sanction third parties or companies for non-compliance.

11. Degree of interest in favor of third parties when government or other types of employees have important inside information

12. When there is non-transparency in decision-making and implementation of a decision or choice of decision.

Public values, value system of judges, prosecutors, states

Four categories of value systems must be distinguished:

- - Personal value system

- - Spiritual value system public values

- - Career value system

- - Family value system

- - Cultural value system

- - Social value system

\section{European human rights}

Dignity

Right to life

Right not the inviolability of the person

The prohibition of eugenic practices for the selection of humans,

Prohibition of turning the human body and its parts into a source of profit

Prohibition of reproductive cloning of human beings.

Prohibition of slavery, torture, and inhuman treatment

\section{FREEDOMS}

- Right to liberty and security, Respect for private and family life, Protection of personal data, Right to marry and to found a family, Freedom of thought, conscience and religion, Freedom of expression and freedom of information / IS THERE ACCESS /, Freedom of assembly and association, Freedom of arts and sciences, Right to education, Freedom of choice of profession and right to work, Freedom of business initiative, Right to property, Right to asylum

\section{EQUALITY}

- Equality before the law, Non-discrimination, Cultural, religious and linguistic diversity, Rights of the child, Rights of the elderly, SOLIDARITY, Right to information, Right to collective bargaining and action, Health protection, Prohibition of child labor, Environmental protection, Protection of consumers

CITIZENSHIP the right to vote and to be elected to the European Parliament

In the right to good administration

\section{Degree of SERVICE OF CITIZENS BY THE ADMINISTRATION}

Right of access to documents, ombudsman - real inefficiency. 
The RICO Law and The MAGNITSKY Law - the solution for fighting corruption and the mafia in European Commission and Bulgaria - on the example of the "real owner" of the state company BULGARIAN POSTS JSC and the theft and loss of an American company for $\$ \mathbf{2 5 0}$ billion

Right to petition free movement of and residence - Whether there is access to this service.

\section{JUSTICE}

The right to an effective remedy and to a fair trial. Presumption of innocence and right to defense.

Principles of legality and proportionality of crime and punishment

Everyone has the right not to be tried or punished twice for the same crime

\section{THE INFORMATION}

Its receipt, analysis, evaluation and use, and the most important dissemination and decision whether to disseminate, Information concerns operational political governance, Illiterate and low-cultured masses, Information is a source of power.

Use of the media by the authorities to conceal information, non-dissemination of true information to information that proves false news, information that reveals the truth for example for the use of public resources, use of optimal information in the interest only or mainly of the rich minority and to the detriment of all the rest.

\section{INFORMATION COMMUNICATION TECHNOLOGIES, INTERNET, SOCIAL NETWORKS}

To use them for manipulation in the broadest sense of the word methods models means of replacing socio-economic, sociopolitical, socio-cultural and other ideas and values, programs, platforms.

Which leads to a subversive motivation for active mass, including political behavior of the poor civic majority.

In favor and especially of the interests of the rich minority

\section{CHANGE OF VALUES, MORALS, IDENTITIES, NEW CULTURAL MODELS}

The neoliberal dominant neoliberal and neo-conservative, ideological-political and moral value system

Imposition of other socio - cultural content, other models, other value systems as opposed to imposed ones, other identities liberal - 34 types of social sexual identity, not gender identity.

Through mass media, internet, social networks imposing new values, new morals, new identities, new cultural models

Replacing the achieved democratic values and morals and imposing other values and morals that are in favor of the rich minority.

Replacement of the individual - personal and group - mass behavior of the voters, and their use for the purposes of the rich minority and the governing power.

Replacement of socio-economic and socio-political and socio-cultural ideas and values and morals.

Models values, model, SUBSTITUTION, imposition of mass culture, which is in favor of the government, the mafia, imposition of new value models, new values, models and patterns of behavior.

Modern information and communication technologies - media, Internet social networks, modern international communications, FOR MANIPULATION, establishment of mass media and mass culture - a new model, new value system, morality, behavior, ideological manipulation and power manipulation - mafia manipulation: mafia manipulation: and Depoliticization, the media perform ideological, political functions.

\section{INEQUALITY is important for Democracy}

Creation and MANAGEMENT OF INEQUALITY BY REPRESENTATIVES OF FINANCIAL BANK RESOURCE TECHNOLOGICAL MAFIOTIZED MATERIALISM.

CONTROL AND GOVERNANCE OF GOVERNMENTS, AUTHORITY by representatives of the FBI MAFIOTIZED MATERIALISM

4. The case of the state company "BULGARIAN POSTS"- JSC - real realization of the conditions of the RICO LAW and MAGNETIC LAW and the mafia in the court, prosecutor's office, the state in Bulgaria, the support of the European Commission of this mafia - the mafia itself, DOLLARS OF AN AMERICAN COMPANY.

4.1./. Factology of the case the state company "Bulgarian Posts"

1 \%. THE OBLIGATION OF THE STATE BULGARIAN COMPANY BULGARIAN POSTS EAD IS BASED ON AN UNFULFILLED CONTRACT FOR RECRUITMENT AND DELIVERY OF SUBSCRIPTION FROM 17.12.1998. WITH NUMBER 027, in which a contract Bulgarian Posts-EAD is obliged for a certain subscription to the magazine "Bulgarian Accountant" of the company "S ......... $\mathrm{k}$......" -EOOD and other books published by the company. 
The RICO Law and The MAGNITSKY Law - the solution for fighting corruption and the mafia in European Commission and Bulgaria - on the example of the "real owner" of the state company BULGARIAN POSTS JSC and the theft and loss of an American company for $\$ \mathbf{2 5 0}$ billion

THE INTEREST FOR DELAY UNDER THIS CONTRACT IS THREE PERCENT PER DAY - CAPITALIZED, and the contract is notarized.

2 \%. THOUSANDS OF PEOPLE SUBSCRIBE TO THE BULGARIAN ACCOUNTANT MAGAZINE AND PAY THE MONEY TO BULGARIAN POSTS EAD, which subsequently pays nothing to the company $S \ldots k \ldots . .$.

3 /. BULGARIAN POSTS EAD has been repeatedly invited WITH INVITATIONS - A TOTAL OF NINE TO PAY ITS DEBT TO THE COMPANY “S. K .... “..

1/. The company "BULGARIAN POSTS" -EAD has signed with the company "ACCOUNTING HOUSE" -EOOD on 17.12.1998. "CONTRACT FOR RECRUITMENT AND DELIVERY OF SUBSCRIPTION" under number 027 / 17.12.1998. , according to which "BULGARIAN POSTS" EAD has accepted on its own behalf and at the expense of the company "S .... K .." - EOOD to conduct the subscription campaign for the visits of the company "S .... K ....." - EOOD on the territory of the country and to deliver the publications of the company to the subscribers recruited for them, against remuneration, which the company" $\mathrm{S} \mathrm{......K} \mathrm{.....} \mathrm{"-}$ EOOD is obliged to pay in the amount and under the terms of the above-mentioned contract. BULGARIAN POSTS\% -EAD does not fulfill the contract and has not yet paid any amounts under this contract. Explicitly in point 7.1. of the contract is written"7.1. IN THE EVENT OF DELAY IN PAYMENTS, THE DEFECTING PARTY SHOULD PAY A PENALTY IN THE AMOUNT OF 3\% OF THE AMOUNT AMOUNT FOR EACH DELAYED DAY".

2 /. Many times the company "S .... K ...." - Ltd. invites the company "BULGARIAN POSTS" EAD to pay the amounts due. In Appendix numbers 2 and 3, INVITATION 4 and INVITATION 6 are attached the next powers of attorney from subscribers who have paid for the subscription of the publication of the company "S ...... K ..... EOOD.

3 /. On 15.06.2001 between the company "S ... K .." - EOOD - ASSIGNOR and the company "D .. D ... K ..." - AD is concluded "CONTRACT FOR TRANSFER OF RECEIVABLES / ASSIGNMENT AGREEMENT /, ACCORDING TO WHICH D .... D ..... K ...... "- AD TAKES OVER THE RECEIVABLE FROM THE COMPANY" BULGARIAN POSTS "EAD.

IN THIS RELATIONSHIP ON 21.08.2001 THE DEBTOR - BULGARIAN POSTS EAD HAS BEEN NOTIFIED OF THE TRANSFERRED RECEIVABLE AND A RECEIVABLE HAS BEEN SUBMITTED.

4 /. ON 13.12.2001 WITH A CONTRACT FOR ASSIGNMENT, THE CLAIM OF THE COMPANY “D D ... K ...." AD FROM THE COMPANY “BULGARIAN POSTS" -EAD UNDER THE CONTRACT 27 / 17.12.1998 WAS TRANSFERRED. TO THE COMPANY “N .......” LTD.

ON 15.06.2001 WITH CONTRACT FOR TRANSFER OF RECEIVABLES / ASSIGNMENT AGREEMENT / COMPANY "DK" - AD ACQUIRES THIS RECEIVABLE from the company "Accounting House".

5/.The BULGARIAN POSTS EAD company has been repeatedly filed to pay its obligation to us under the respective contract concluded between the company.

contract as follows:

5.1./. presentation by telegram with return receipt dated 21.08.2001. for millions of euros.

5-2- /. telegram with return receipt dated 14.12.2001 to transfer the obligation.

5.3./. presentation by telegram with return receipt dated 15.12.2001. for millions of euros ..

6 /. ON 10.05.2005 PAYMENT OF PAYMENT TO THE COMPANY BULGARIAN POSTS EAD / NOTIFICATION LETTER FOR ASSIGNMENT / WITH INCOMING NUMBER 95-G-2 / 10.05.2005 WAS MADE. WORTH millions of euros ..

7 /. ON 03.01.2005 WITH INCOMING NUMBER 32-02-1, a NOTIFICATION LETTER FOR GRANTING A PERMIT BY THE MINISTRY OF TRANSPORT TO THE MINISTRY OF TRANSPORT AS A PRINCIPAL OF THE AMERICAN PRESIDENT

8/. ON 28.03.2005 WITH INCOMING NUMBER NUMBER 32.02-1 was submitted "REQUEST-REQUEST" FOR ENTRY INTO ACTION AND FOR MEETING TO SETTLE ALL DETAILS OF CONCLUSION OF THE CONTRACT.

5 /. MORE ON THE DATE 10.05.2004 the acquirer CLAIMS PART OF HIS CLAIM. THE SUBMISSION IS NOT DISPUTED, NOT PROTESTED, NOT OBJECTED BY BULGARIAN POSTS EAD. That is, it is accepted.

6 /. NADATA 21.10.2004 the acquirer MAKES A REQUEST FOR A MEETING WITH MINISTER Nikolay VASILEV - MINISTER OF TRANSPORT, whose ministry is the principal - sole owner of the state company "Bulgarian Posts" EAD, EXPRESSING READYNESS READINESSNESS

7 /. DURING THE CABINET, SAXO-BURGOTIAN PRESSURES the representatives of the acquirer TO CONCLUDE COMMISSION AGREEMENTS - ILLEGAL. There is also surveillance by a mafia group. There are bombs placed under the executive director's car. For two months he was followed by people from a mafia group. 
The RICO Law and The MAGNITSKY Law - the solution for fighting corruption and the mafia in European Commission and Bulgaria - on the example of the "real owner" of the state company BULGARIAN POSTS JSC and the theft and loss of an American company for $\$ \mathbf{2 5 0}$ billion

8/. ON 06.04.2006 the acquirer PRESENTS OUR DAMAGES CAUSED - LOSSES

9 /. CONSEQUENTLY, THE CLAIM FROM THE COMPANY "DK" AD WAS TRANSFERRED TO THE AMERICAN COMPANY "GM" AD.

\section{2./. THE POTENTIAL OF THE STATE COMPANY “BULGARIAN POSTS"JSC IN BULGARIA}

At least 3000 offices and premises of an average of at least 300 - 600 square meters in all regional cities, large cities, medium-sized cities, small towns in Bulgaria, even villages.

\section{3./. SUBMISSION OF A COMMERCIAL CASE IN SOFIA CITY COURT UNDER NUMBER 1456/2006 BY THE AMERICAN COMPANY AGAINST THE STATE COMPANY BULGARIAN POSTS EAD - DISAPPEARED CASE}

The American company G...M.. LLC filed a commercial case in the Sofia City Court under number 1456/2005.

ON THIS CASE AT ONE OF THE COURT SESSIONS THE UNCONDITIONED "CONCLUSION" FOR THE ACCOUNTING EXPERT EXAMINATION ON THIS CASE № 1456/2005 OF THE SCC WAS ADOPTED IN THE COURT SESSION ON 25.09.2006. FROM 10.30 AM AS THE OBLIGATION AS OF 20.06.2005. to the American company by the state company "Bulgarian Posts" EAD It is determined by the accounting expertise as of 25.09.2006. in the amount of EUR 293,985,612,515,337,000,000,000,000,000,000,000,000. AND ONLY ON THE PRINCIPAL 45,000 / forty-five thousand / euros, NOT AS THE DEBT ON THE PRINCIPAL 142,500 EUROS.

The commercial case disappeared in the Sofia City Court and the entire judicial system in Bulgaria by order of the mafia and the executive branch.

4.4./. REQUESTS to the Prime Minister BOYKO BORISOV and the Minister of Transport to comply with the laws of the Republic of Bulgaria, as the request was entered under number 4461 dated 30.07.2010. and to the Minister of the Ministry of Transport with registration № 32-02-2453 dated 0907.2010.

With the request the AMERICAN COMPANY uses its rights under Art. 295 para 1 of the Commercial Law and ON THE BASIS OF PREPARED AND ACCEPTED BY BULGARIAN POSTS - FROM A CONCLUSION BY AN EXPERT UNDER CITY CASE 1456/2005. ON THE INVENTORY OF THE SOFIA CITY COURT, FROM WHICH CONCLUSION IT IS SHOWN THAT THE OBLIGATION OF THE COMPANY "BLAGRASKI POSTI" EAD TO OUR COMPANY UNTIL 20.06.2005 IS IN THE AMOUNT OF EUR 293,985,612,515,337,000,000, 000,000,000,000,000

AND IN CONNECTION AND ON THE BASIS OF ART. 1 PARAGRAPH 2 OF THE STATUTE OF BULGARIAN POSTS EAD

ON THE BASIS OF ART. 4 OF THE COMMERCIAL LAW AND IN CONNECTION WITH ART. 187E PARAGRAPH 1 POINT 1 OF THE COMMERCIAL LAW

AS WELL AS ACCORDING TO ARTICLES ART. 130 - SECOND PART OF ART. 131 - THE FIRST PART I Art. 132 - PART TWO OF THE LAW ON OBLIGATIONS AND CONTRACTS

AND BECAUSE IN ACCORDANCE WITH ART.

The request is for the transfer of $100 \%$ / one hundred percent / of the shares owned by the state as a principle of the Ministry of Transport in the company "Bulgarian Posts" EAD to the American company.

None of this is done. The laws of the state of the Republic of Bulgaria are not implemented by the Prime Minister BOYKO BORISOV.

Arson followed in 2011. of the apartment of MD. Where his parents would have been burned alive, one of his fathers - in bed. Followed by death threats from relatives of Tsv. Borislavova, close to the Prime Minister Boyko Borissov.

On 06.07.2011 after the death threats it was submitted to the Council of Ministers under ent. Number 3655 QUESTION TO THE PRIME MINISTER BOYKO BORISOV:

"REQUEST FOR ANSWER from the Prime Minister BOYKO BORISOV:

$1 \%$ ON THE BASIS OF THREATS OF DEATH AGAINST ME FROM COMPANIES CLOSE TO YOUR POWER AND PERSONS INTERESTED IN THE PRIVATIZATION OF BULGARIAN POSTS EAD

2 /. IS THERE AN ORDER FROM THE EXECUTIVE POWER TO THE ADMINISTRATIVE AND OTHER COURTS TO DISAPPEAR CASES AGAINST STATE INSTITUTIONS, MINISTER OF MINISTERS. 
The RICO Law and The MAGNITSKY Law - the solution for fighting corruption and the mafia in European Commission and Bulgaria - on the example of the "real owner" of the state company BULGARIAN POSTS JSC and the theft and loss of an American company for $\$ \mathbf{2 5 0}$ billion

\section{3 /. IS THERE AN ORDER FOR DESTRUCTION OF WHOLE FAMILIES THROUGH THE NRA AND THE PROSECUTOR'S OFFICE."}

There is no answer from the Prime Minister BOYKO BORISOV.

Instead, deputies from the GERB political party voted to remove the state-owned company Bulgarian Posts from the banned list of companies for privatization.

It is rumored that Boyko Borisov has already bought the company "Bulgarian Posts" EAD.

As a result - on 21.09.2011. attempted murder of the executive director of the AMERICAN COMPANY by setting fire to the apartment where he and his parents live.

Only 10 centimeters saved one of MD's parents from burning like a torch, and the other would burn immediately - because he was lying motionless on a bed.

4.5./ ACCORDING TO THE STATUTE OF BULGARIAN POSTS EAD ART. 1 AL. 2 "THE STATE IS RESPONSIBLE FOR THE OBLIGATIONS OF THE COMPANY UP TO THE AMOUNT OF THE AMOUNTS OR DUE DAYS AGAINST THE SUBSCRIBED SHARES.

The American company has the legal right to be transferred at least $95 \%$ of the shares of the state company "Bulgarian Posts" EAD.

ADDITIONAL DOCUMENTS:

1 //. NOTIFICATION LETTER 03.01.2005 TO MINISTER VASILEV

2 //. REQUEST TO THE PRIME MINISTER OF THE REPUBLIC OF BULGARIA THEN SERGEY STANISHEV FROM 13.09.2006

WITH REG. № 13-00-265 IN THE MINISTRY OF TRANSPORT AND NUMBER 4461 IN THE COUNCIL OF MINISTERS.

3 //. TO THE PRIME MINISTER SERGEY STANISHEV FROM 31.07.2006 UNDER NUMBER 4461 ANSWER

4 //. ANSWER TO THE COUNCIL OF MINISTERS FROM 29.08.2006 UNDER NUMBER 4461

5 //. LAST REQUEST TO PRIME MINISTER SERGEY STANISHEV FROM 22.05.2009 AND MINISTER MUTAFCHIEV - MINISTER OF TRANSPORT.

6 //. INVOICE FOR 150 BILLION EUROS - № 7 FROM DATE 19.12.2008.

7 //. REQUEST FOR ANSWER FROM THE PRIME MINISTER BOYKO BORISOV FROM 06.07.2011 WITH ENTRY NUMBER 3655.

8/. LETTER TO THE THEN PRIME MINISTER ORESHARSKI 2013

4.6./. SUBMISSION OF A CASE OF A CREDITOR - the American company for OPENING BANKRUPTCY PROCEEDINGS in the Sofia City Court of the state company "Bulgarian Posts".

SUPPORT OF JUDGE MAFIA who violate the laws of the Republic of Bulgaria, MANDATORY DIRECTIVES OF THE EUROPEAN COMMISSION

Lawlessness and violation of the law by judges Radoslava Simeonovo from Vratsa District Court, judges Glozhenska, Bozhikov, Spasov from the Plovdiv Court of Appeal, judges from the Supreme Court of Cassation - Tanya Raykovska, Daria Prodanova, Totka Kalcheva, Nikola Hitrov, Eleono in favor of the MAFIA in BULGARIA

VIOLATED THE MANDATORY DIRECTIVE 2008/6 / of the European Union and the European Commission from 01.01.2010. according to which from 01.01.2010 the state-owned company Bulgarian Posts has no monopoly on its activities and the same monopoly has been revoked as of January 1,2011 . .

The application for opening of insolvency specifies that the state company "Bulgarian Posts" EAD from 31.12.2010. does not exercise a STATE MONOPOLY over those specified in Art. 24 of the Postal Services Act - STATE MONOPOLY according to the Directive of the EUROPEAN COMMISSION - Directive 2008/6 / EU, which is mandatory for all judges in Bulgaria.

The date of filing the application for opening insolvency proceedings is 11.07.2011. - Seven months after the STATE MONOPOLY and the state have ceased to exist, the company Bulgarian Posts EAD actually does not have one, which is not an obstacle for declaring the state company bankrupt.

The bankruptcy petition explicitly states that there is a recognized and accepted, and undisputed and not objected in time OBLIGATION of the state company "Bulgarian Posts" to the American company for a minimum of 150 billion euros by virtue of an invoice issued by the American company to the state company, as the state company received this letter on 25.05.2009.

In addition, the EU states the condition for a state-owned company to be declared bankrupt as:

1. The debtor is a trader. 
The RICO Law and The MAGNITSKY Law - the solution for fighting corruption and the mafia in European Commission and Bulgaria - on the example of the "real owner" of the state company BULGARIAN POSTS JSC and the theft and loss of an American company for $\$ 250$ billion

2. The debtor is insolvent.

3. The debtor is not a bank or an insurance company.

4. The debtor according to the concluded "CONTRACT FOR COLLECTION AND DELIVERY OF SUBSCRIPTION" 027 / 17.12.1998. AND TRANSFERS - ASSIGNMENT CONTRACTS FROM THE COMPANY "S ... K ...." EOOD TO THE COMPANY "D ... D ... K ..." - AD AND CONSEQUENTLY TO THE AMERICAN COMPANY “G ... M. .. „Ltd. HAS NOT BEEN EXTENDED DESPITE THE REPEATED INVITATIONS FOR THIS.

The complete factology is specified.

The obligation to the American company to the last capitalization requirement without interest and delay until the date of filing the claim mob in the amount of EUR 293,985,612,515,337,000,000,000,000,000,000,000,000,000,000 is determined - as evidenced by the case adopted in civil case 1456/2005. of the Sofia City Court conclusion for performed forensic accounting expertise, adopted on 25.09.2006. from the debtor "Bulgarian Posts" and not disputed.

le there is a confirmation of the balance on the obligation of the company "Bulgarian Posts" after the debtor company has been invited in time and in the respective term has not made any objection, on the amount of its obligation, they ...

The notification letters to the tax administration dated 10.06.2009 are attached. with entry number 26-G-3599 and to the State Receivables Agency dated 11.06.200. with ent. Number 22-00-247.

THE CAPITAL OF THE COMPANY "Bulgarian Posts" is insufficient to satisfy our claim.

The debtor is insolvent because he is unable to fulfill the required monetary obligation to the American company in the amount of EUR 293,985,612,515,337,000,000,000,000,000,000,000.

The court was asked:

1/. To declare the company "Bulgarian Posts" insolvent and determine the start date according to Art. 630 para 1 item 1-5 incl. of the Commercial Law

2 /. To initiate insolvency proceedings against Bulgarian Posts EAD.

TO ANNOUNCE BULGARIAN POSTS EAD IN NON-PAYMENT

3 /. To allow collateral under Art. 628, para 1, para 1 item 5, para 2 by foreclosure of all real estates of the debtor in the Republic of Bulgaria.

3.1 /. The application is well-founded, lawful and admissible.

FOLLOWS THE LAWLESSNESS OF THE JUDGES EXECUTING THE ORDER OF THE MAFIA as follows:

Judge Radoslava Simeonova of the Vratsa District Court terminated civil case 31/2010 because the company Bulgarian Posts “HAD A MONOPOLY - with an Order

The judges of the Court of Appeal Plovdiv - Glozhenska, Bozhikov, Spasov with a ruling on chtd. 689/2011 - 2nd panel confirm the reopening of the case

The judges of the Supreme Court of Cassation Hitrov, Chanacheva, and Markov ruled in the Supreme Court of Cassation on case No. 798/2011 № 899 of 19.12.2011 in the Supreme Court of Cassation - Commercial Chamber - they confirmed the termination.

le There is evidence of NON-COMPLIANCE, NON-COMPLIANCE, NON-COMPLIANCE, VIOLATION, NON-COMPLIANCE by Judges Hitrov, Emil Markov, Chanacheva, Glozhenska, Bozhikov, Spasov, and Radoslava Simeonova of the laws of the Union of Bulgaria and the Republic of Bulgaria. The European Union and the European Commission from 01.01.2010, according to which Bulgarian Posts does not have a state monopoly.

Ie THERE IS UNCONDITIONAL PROOF OF LAWLESSNESS COMMITTED BY JUDGES.

In the meantime, the PRIME MINISTER OF THE REPUBLIC OF BULGARIA, Mr. Prof. Gerdjikov, COUNCIL OF MINISTERS - Sofia1574, 1 Dondukov Blvd., and the MINISTER OF TRANSPORT, Ministry of Transport and Information Technologies, are also required to comply with the law. -1000, 9 Deacon Ignatius Street.

NO RESULT. AGAIN REFUSAL OF IMPLEMENTATION OF THE LAWS OF THE REPUBLIC OF BULGARIA.

This was followed by a request for annulment of entered into force court decisions - the ruling of the Supreme Court of Cassation on chtd. 5748/2012 № 600 from 22.10.2012- SCC Chamber of Commerce., Order of the SCC, so-called case $519 / 2012$, Order of the Vratsa District Court on civil case 31/2010 
The RICO Law and The MAGNITSKY Law - the solution for fighting corruption and the mafia in European Commission and Bulgaria - on the example of the "real owner" of the state company BULGARIAN POSTS JSC and the theft and loss of an American company for $\$ \mathbf{2 5 0}$ billion

The judges of the Supreme Court of Cassation - Tanya Raykovska, Daria Prodanova, Totka Kalcheva, again violate the laws and do not comply with the laws.

\section{7./ SESSION OF THE PROSECUTOR'S OFFICE AND PERSONALLY OF THE MAIN CHIEF PROSECUTOR SOTIR TSATSAROV fOr} the lawlessness of judges in cases and HIS INACTION

Inaction of the prosecutors and personally notified the Chief Prosecutor SOTIR TSATSAROV for inaction of the Prime Minister Boyko Borisov and ministers of transport in connection with huge obligations of the state film "Bulgarian Posts" EAD and non-compliance with the laws of this country. lost billions

Attached to the CHIEF PROSECUTOR SOTIR TSATSAROV - evidence attached to Prime Minister Boyko Borisov, Minister Moskovski, Minister Tsvetkov, Prime Minister Oresharski, Prime Minister Prof. Gerdjikov, and dozens of other EVIDENCES since 2010. because the Ministers of Transport of BOYKO BORISOV do not comply with the laws of the Republic of Bulgaria - the Commercial Law, the Law on Obligations and Contracts in connection, the Articles of Association of Bulgarian Posts EAD as a principal in connection with the proven obligation of case 1456/2005 Bulgarian Posts EAD to Goldman Management LLC and the actual non-fulfillment of Art. 295 para 1 of the Commercial Law, art. 2 of the Articles of Association of Bulgarian Posts EAD Art. 187E of the Commercial Language, Art. 130,131 and 132 of the Law on Obligations and Contracts for transfer of $95 \%$ of the shares of the company "Bulgarian Posts" -EAD to the company "Goldman Management" LLC.

Indisputable evidence was attached to the Chief Prosecutor SOTIR TSATSAROV that judges from the Supreme Court of Cassation - Tanya Raykovska, Daria Prodanova, Totka Kalcheva, Nikola Hitrov, Eleonora Chanacheva, Emil Markov from the Supreme Court of Cassation - judges from Glozhenska, Bozhikov, Spasov from Apela violate the Bulgarian and European laws deliberate violation of the mandatory directive 2008/6 / EU of the European Union and the European Commission from 01.01.2010. according to which from 01.01.2011 the state company Bulgarian Posts EAD does not have a monopoly on its activity, and the same monopoly has been revoked as of January 1, 2011. and actually caused losses in a particularly large amount, fulfilling an order of the executive branch.

The same judges have allowed themselves under item 519/2012 of the Supreme Court of Cassation, under case file 798/2011, case file 689/2011, of the Court of Appeal Plovdiv, under case file 3765/2013 to confirm the termination of the case for declaring insolvency of the company "Bulgarian Posts" EAD for its liability in the amount of over 100000000000 / one hundred billion / euros, and actually in addition to violating the laws and caused the above huge loss, CARRIED OUT ONLY IN FAVOR OF THE STATE MAFIA, IN FAVOR OF CRIMINAL ACTIONS OF MINISTERS, EXECUTIVE DIRECTORS OF THE STATE FIRM FIRM.

On 28.02.2012 in a REFERENCE TO THE SCC, it is established that the ORDER OF 19.12.2011. № 899 ON CH.T. CASE № 798/2011 WAS DECIDED BY THE SAME JUDGES FOR WHICH WE HAVE ASKED NOT TO RULE ON THE PRIVATE CASSATION APPEAL - NAMELY: JUDGE HARICHAIATI NIACO EVEN MORE, JUDGE CHANACHEVA REJECTED OTHERS LEAD BY THE COMPANIES.

EVEN MORE, THAT THE JUDGES OF THE SUPREME COURT OF CASSATION HAVE MADE A DECISION PROVING A VIOLATION OF THE LAW, SINCE 01.01.2011. BULGARIAN POSTS EAD DOES NOT HAVE A MONOPOLY ON ITS ACTIVITY, AND THE SAME MONOPOLY HAS BEEN REVOKED AS OF JANUARY 1, 2011. by the EUROPEAN COMMISSION.

SEPARATELY FROM THIS ACCORDING TO THE DIRECTIVE OF THE EUROPEAN UNION 2008/6 / EU, WHICH IS MANDATORY FROM 01.01.2010. THE MONOPOLY OF THE COMPANY BULGARIAN POSTS EAD HAS BEEN REMOVED.

THIS DIRECTIVE IS MANDATORY FOR ALL BULGARIAN JUDGES.

The Chief Prosecutor SOTIR TSATSAROV has been repeatedly informed that the Prime Minister Boyko Borissov has been personally informed that his MINISTER MOSKOVSKI DOES NOT FULFILL THE LAWS OF THIS STATE AND STATUTES KASHAT NASHAT

DESPITE THE REQUESTS TO BOYKO BORISOV FROM 29.03.2016. NO REACTIONS FOLLOWED OR BY PRIME MINISTER BOYKO BORISOV.

4.8./. REQUESTED BY THE PRESIDENT OF THE EUROPEAN COMMISSION - JEAN CLAUDE JUNKER THE EUROPEAN COMMISSION in connection with REQUEST -7, entered in the Representation of the European Commission in Bulgaria 01.03.2017. to implement the laws of the EUROPEAN UNION and to sanction Bulgaria for non-compliance, non-application of the MANDATORY DIRECTIVE 2008/6 / EU of the EUROPEAN UNION and the European Commission from 01.01.2010.

NO REACTION AND NO ENFORCEMENT OF THE LAW BY THE EUROPEAN COMMISSION.

A request was made for assistance to the President of the United States, Barack Obama, and subsequently to the President of the United States, Mr. Donald Trump, for assistance regarding and concerning the real property of the American company. 
The RICO Law and The MAGNITSKY Law - the solution for fighting corruption and the mafia in European Commission and Bulgaria - on the example of the "real owner" of the state company BULGARIAN POSTS JSC and the theft and loss of an American company for $\$ \mathbf{2 5 0}$ billion

NO RESULT. NO REACTION.

Requests to the Prime Minister BOYKO BORISOV dated 09.07.2010. reg. № 32-02-2453

Requests to the Prime Minister PLAMEN ORESHARSKI ent. № 11-00-393 / 12.08.2013

Request to the Prime Minister SERGEY STANISHEV dated 22.05.2009. and dozens of others to YOU personally.

4.9./. It was requested by THE EUROPEAN COMMISSION with President Jean-Claude Juncker and then President Ursula von der Layen - to comply with the laws of the EUROPEAN UNION in connection with the lawlessness committed in Bulgaria in the case.

No RESULT

ATTACHED to the European Commission and to Ms. von der Leyen's personal EVIDENCE of the European Commission and the EUROPEAN UNION ON THE MAFIA IN THE PROSECUTOR'S OFFICE OF THE REPUBLIC OF BULGARIA led by SOTIR TSATSAROV, Chairman BOYKO BORISOV, of the mafia in state institutions such as the National Revenue Agency, for the MAFIA IN PRIVATE JUDICIAL EXECUTION,

AND APPROPRIATELY REQUESTED by the EU and personally by von der Leyen to take measures against THIS MAFIA and A REQUEST WAS MADE TO IMMEDIATELY appoint continuous Monitoring of the state - Republic of Bulgaria, the court, the prosecution, the private enforcement of state institutions and agencies

MONITORING OF THE ENTIRE STATE OF THE REPUBLIC OF BULGARIA IS REQUIRED

IMPLEMENTATION OF FULL MONITORING OF THE JUDICIAL SYSTEM IS REQUIRED due to imposed corrupt practices by courts and at all levels - SCC, SCC and others

FULL MONITORING OF THE JUDICIAL SYSTEM IS REQUIRED DUE TO IMPOSED CORRUPTION PRACTICES BY THE PROSECUTOR'S OFFICE OF THE REPUBLIC OF BULGARIA MANAGED BY THE PROSECUTOR PROSECUTOR

REQUEST FOR SEIZURE of all amounts under European programs authorized by the European Union and the European Commission to the Republic of Bulgaria

There was no reaction from either von der Layen or Juncker.

With the REPORT of the European Commission dated 13.11.2018. Com (2018), (SWD * 2018) 550 final) and the Report dated 22.10.2019. The European Commission proves that it FULLY SUPPORTS THE MAFIA IN BULGARIA - the mafia state administration of the Prime Minister BOYKO BORISOV, the mafia prosecutor's office headed by SOTIR TSATSAROV, the mafia in the judiciary, the mafia in the European Ministry of Transport PROVES THAT SHE IS THE MAFIA.

\subsection{0./. SUBMISSION OF AMOUNTS FOR CAUSED LOSSES OF 250 BILLION EURO TO BULGARIA, THE EUROPEAN COMMISSION} OF THE AMERICAN COMPANY.

5 /. September 2005 The representative of the American company addresses the head of the MAFIA in BULGARIA GENERAL LYUBEN GOTSEV.

After 15 days the lawyers of General LYUBEN GOTSEV consider the case DECLARE:

THE AMERICAN COMPANY is right, it is the real owner of the state company BULGARIAN POSTS.

After General LYUBEN GOTSEV UNDERSTAND who the representative of the American company was, he stated:

„MD. WE CAN NEVER RIDE HIM !! "HE IS A MAN OF HONOR, THERE ARE NO MISTAKES IN HIS LIFE !!

\section{CONCLUSION}

The described case is striking and proves the huge mafia and corruption both in Bulgaria and in the European Commission, the lawlessness, the mafia in court, the prosecutor's office, which fully supports this mafia and the lawlessness in Bulgaria, how judges do not respect the laws of the mafia. and causing losses to an American company - the real owner of the company "Bulgarian Posts".

\section{LITERATURE REVIEW}

1) Dobrev, M. (2015) Theory of generating crises, Bulukrain-MM, Sofia, BG

2) Dobrev, M. (2016). Is there a mafia in the European Commission and Union?!? 1, Bulukrain-MM Sofia.BG

3) Dobrev, M. (2014). Theory of the corruption and Theory of the mafia, Bulukrain-MM, Sofia., BG 
The RICO Law and The MAGNITSKY Law - the solution for fighting corruption and the mafia in European Commission and Bulgaria - on the example of the "real owner" of the state company BULGARIAN POSTS JSC and the theft and loss of an American company for $\$ \mathbf{2 5 0}$ billion

4) Dobrev, M. (2013). Theory if degree of trust, Bulukrain-MM, Sofia, BG.

5) Dobrev, M. (2010). Theory and praxuse of the Mafiotismus. Bulukrain-MM. Sofia

6) Dobrev, M. (2019) "The mafiotism in the EU, ECommission, E Parliament!?!?! And its protection with Gemany, France, Englans - the mafia in court, prosecutors, government in Bulgaria over ten years !!! The dept of EC and EU of houndret billions USD !!! "Bulukrain-MM. Sofia

7) Dobrev. M. (2018) "Theory and practice of Mafiotismus. Finance-banking resource technological mafia-driven Materialism "- Bulukrain-MM, Sofia

8) Dobrev, M., Garibova-Dobreva, Mariola (2020) The new old world order.- Bulukrain-MM, Sofia

9) Dobrev, M, Garibova M, /2020/ The Mafia, Mafia and Financial Bank Resource Technological Mafia Materialism - THE NEW OLD WORLD ORDER Bulukrain-MM

10) Dobrev M. Goribova-Dobreva. /2020/ THE PLAN FOR COVID 19 THE PANDEMIC - THE THIRD WORLD WAR - the attempt to impose a NEW WORLD ORDER by the representatives of Promf Momchil Dobrev financial banking resource technological mafia Materialism for control of the whole planet, nations, people, Euro, children, USA and companies. Bulukrain-MM

11) Dobrev. M. Garibova-Dobreva M. /2020/RESTART OF CIVILIZATION - without mafia and financial banking resource technology in mafia Materialism - THE ONLY SOLUTION! Our suggestion. Bulukrain-MM

12) Dobrev, M. Garibova-Dobreva, M. /2020 חRESIDENT DONALD TRUMP and TRUCK'S DOCTRINE against mafiaism, financial banking resource technological mafia materialism, Wars, the new Old World Order1 Our proposal for RESTART OF CIVIL. Bulukrain-MM

13) Dobrev. M., Garibova-Dobreva.M. /2020/ THE GREAT RESET with the COVID-19 the real "the Third World War" - to impose a NEW WORLD ORDER on the new Holocaust, genocide, dictatorship of DIGITAL MAFIOTISMUS. Bulukrain-MM.

14) Dobrev. M, Garibova-Dobreva.M. / 2020 / The COVID-19 pandemy - the real "the Third World War" - to impose a NEW WORLD ORDER on the new Holocaust, genocide, dictatorship of DIGITAL MAFIOTISMUS. Bulukrain-MM

15) Dobrev,M. Garibova.M. /2018/ THE GENIUS OF PROF. MOMTCHIL DOBREV- HALACHEV and his theories, Theory of degree of trust, Theopry of degree of truth, Theory of mafia, Theory of corruption., Theory of vortex fields. Theory and practice of free energy. Cosmological theory of information. Theory of information-energy-medicine, - genetics, psychology, - psychoiatry, - archeology., Theory and practice of mafiotismus, Theory of unversum, Finance-bankinh resource technological mafia-driven Materialismus Bulukrain-MM. 